\title{
Virgilijus Pugačiauskas. Napoleono administracija Lietuvoje [Napoleon's Administration in Lithuania]. Vilnius: Vaga, 1998. Pp. 216. ISBN 5-415-01319-9
}

This study is devoted to a brief, but nevertheless most impressive period in the history of Lithuania - the year 1812. The events of that year are brought to light by the author in an attractive way without going into any great details.

The Napoleonic Wars are not a new topic in Lithuanian historical scholarship. Nevertheless, this young historian has managed to find his 'niche' in the investigation of this period to look at it from a new point of view. The problems, peculiar to the year 1812 are analyzed by the author mostly on the basis of archival materials. The subject of the study is the Département de Vilna and its activity. The author investigates the internal structure of the French administra tion and compares it with that of the political power of the GDL. Particular attention is paid to the behaviour of the officers of the prefectures and the administrative commission of the Département during the reforms. Napoleon's policy toward Lithuania is investigated from aspects, which have not been researched so far: the French knowledge about Lithuania, the organization of the Lithuanian regular army, etc. The discussion of French political projects in Lithuania is based on French knowledge of the history of the GDL and its situation in the early nineteenth century. The author uses journalistic social-political publications to reveal the mechanism of French propaganda and the way in which it manipulated the various layers of society, in particular with respect to the gentry.

In his conclusions Virgilijus Pugačiauskas indicates that the French rule revealed a different perspective for the social and political life of Lithuania and new conceptions of the country's reconstruction. However, the period was too short to leave any significant changes in the consciousness of Lithuanian society.

Rima Praspaliauskienè 